\title{
Does Mobility Matter for Attitudes to Europe? A Multi- level Analysis of Immigrants' Attitudes to European Unification
}

\author{
Antje Roeder \\ Political Studies \\ Volume 59, Issue 2, pages 458-471, June 2011
}

Keywords:

European integration;migration;mobility;Euroscepticism

\begin{abstract}
Support for Europe is largely argued to be based on the self-interest of individuals as well as being influenced by their national identity. Relatively little is known, however, about the attitudes of immigrants regarding Europe, although they form a growing part of the European population and are strongly affected by European policies. In this article, attitudes of immigrants towards European unification are analysed to determine how far they differ from the native population and between immigrants from different regions. The main theories on attitudes towards Europe would predict overall more positive attitudes. First, self-interest should lead migrants to evaluate Europe more favourably, as certain groups in particular have gained from it in the past mainly in terms of enhanced mobility and legal rights as immigrants, and can realistically expect to gain more in the future. Secondly, being an immigrant as opposed to a native citizen can be expected to have an impact on national identities, with the supranational level likely to be more attractive to people with multiple national affiliations. Findings confirm this, and highlight that migration status, region of origin and citizenship status are important predictors of attitudes. Furthermore, explanatory factors related to economic interests, which have been shown to be of major importance for natives, matter less for immigrants. It would appear that issues related to mobility and a less exclusively defined national identity may be of more importance for immigrants' attitudes than socio-economic position.
\end{abstract}

Despite many delays and difficulties, European integration has been progressing, and the enlargement of the European Union is likely to continue. It has often been claimed that the European project is largely an aspiration of political elites, and that unification and enlargement are not always supported by the population (Vetik, 2003). Indeed it cannot be denied that there is quite 
widespread Euroscepticism among certain groups of the population (Weßels, 2007), which most recently and prominently found its expression in Ireland's rejection of the Lisbon Treaty in the first referendum (Quinlan, 2009). Often this is due to people's fear about losing out economically and in terms of political influence (Anderson and Reichert, 1996; Eichenberg and Dalton, 2007). Also the European Union aspires to be more than an economic and political cooperation, and the European identity at times competes with national and regional identities, fuelling fears that cultural differences will be levelled as a result (Carey, 2002). Who, then, supports Europe, and why?

Political attitudes are argued to be primarily the outcome of rational processes based on self-interest and ideational processes that are linked to emotional and affective attachments of people (Easton, 1975). Attitudes to Europe similarly are generally claimed to be the result of individuals' calculations of cost and benefits. Most of the debate focuses on economic factors both on the level of states and in terms of individual redistributive concerns (Anderson and Reichert, 1996; Eichenberg and Dalton, 2007; Gabel, 1998; for transition countries see Tucker et al., 2002). More recently, self-interest has been argued to be of importance not only in terms of economic benefits, but also in relation to social well-being (De Vries and Van Kersbergen, 2007). This builds on other work which shows that individuals who feel that their national identity is threatened by Europeanisation are less supportive of Europe (Franklin et al., 1994), with communal identity being an even more important predictor of opinions than economic calculus (Hooghe and Marks, 2005).

While much research has been concerned with people's attitudes regarding the EU, one interesting question has been neglected so far, namely how immigrants think about Europe. Migrants from other EU countries as well as third countries make up a sizeable and increasing proportion of the population in Europe (Münz et al., 2007; Stalker, 2003). Free movement of people is one of the core features of European unification, and has facilitated the migration of many (Favell, 2008). Several European initiatives have indeed focused on enhancing and supporting intra-Union mobility, partly with the explicit aim of increasing support for Europe (Recchi, 2008). Indeed, Nina Rother and Tina Nebe (2006) found in the European Internal Movers Social Survey that citizens from other European states living in France, Germany, Great Britain, Italy and Spain were significantly more supportive of the EU and felt more European than the rest of the population. Issues related to mobility and rights as European citizens can be expected to inform at least partly the political interests of immigrants with regards to support for further European unification, although this issue has received little attention so far.

In the past, the position of immigrants moving from one EU-15 country to another has been vastly improved due to gaining largely the same rights and entitlements as the native population (Day and Shaw, 2002). At the time of data 
collection for the survey used here, enlargement of the EU was ongoing, and benefited migrants from new EU member states, although they had some restrictions regarding labour market access placed on them by most of the EU-15 countries (Recchi, 2008). For countries at the borders of Europe, enlargement is likely to play a larger role in migrants' interests than further unification of the already existing states. Inclusion of their country in the free movement area would facilitate their contacts to the origin country, and depending on their status within the country, lead to improved legal and political rights.

Second, individuals who have migrated are less likely to feel threatened in their national identity by Europe, but might actually identify more with a European identity (Recchi, 2008). This is, first, due to their own uprooting and the experience of migration (Rumbaut, 2005), but also to the likely self-selection of migrants. Less parochial individuals are more likely to decide to migrate than people with strong local ties and sense of belonging (Mincer, 1978). Consequently it can be expected that, in addition to the above reasons, immigrants in general will be quite positive about the EU and support its institutions and policies because they are less focused on the national level and perceive less threat to their identity from European unification.

In the following, I summarise the main theoretical explanations for variations in support for European integration, namely self-interest and national identity, and examine how these explanations may apply differently for immigrants. I then discuss the data used and the methodological approach, before reporting the findings. This research note aims to contribute to the growing literature on attitudes towards the European Union by focusing on immigrants rather than the general population. Certain groups of immigrants have most certainly benefited from European integration, yet their attitudes have not so far been analysed sufficiently to determine if this finds an expression in more support for the European project. I argue that the no borders regime of the EU may be perceived as a threat by native populations, but creates opportunities for migrants, facilitates their mobility and improves the status of certain groups once settled in a host country, which is likely to be reflected in their attitudes.

\section{The Cost and Benefit of European Integration for Immigrants}

Different theories have been brought forward to explain variations in individuals' support for European integration. Probably the most prominent one claims that economic calculations of cost and benefit shape individuals' political attitudes, including those towards Europe. Individuals who are more likely to benefit from membership of the EU are generally more positive towards it (Anderson and Reichert, 1996; Eichenberg and Dalton, 2007; Gabel, 1998). In individual terms this is primarily in relation to the level of human capital they possess, as trade liberalisation usually favours those with higher education and skill level, whereas low-skilled workers are more likely to experience more 
competition as well as suffer if welfare states come under increased pressure (Anderson and Reichert, 1996; Gabel, 1998; Gabel and Palmer, 1995; Huber and Stephens, 2001; Tsoukalis, 1993; for transition countries see Tucker et al., 2002).

With regard to immigrants, another level of self-interest may enter into this. Certain groups of migrants have gained from European integration in terms of freedom of movement within the Union, and increased rights in their host countries. EU-15 migrants can live and work in any of the other European member states and have equal rights to citizens of these states with some minor exceptions (Day and Shaw, 2002). Individuals from the accession states have had some restrictions placed upon them by most EU-15 countries in terms of access to their labour markets which are gradually being removed (Recchi, 2008). Further European unification may also hold benefits for migrants from other countries, as the EU is attempting to achieve a common framework on migration from third countries (European Commission, 2007). Individuals who have gained from increased mobility and improved legal status due to European unification as well as those who may have more to gain in the future can be expected to be more in favour of unification.

Since immigrants' rights are not only determined by their origin country, but also by citizenship status, support for Europe is likely to differ between migrants who are citizens of the host country and those who are not. For migrants within the EU-15 territory, citizenship does not afford significantly more rights than they already enjoy as intra-EU migrants, with some exceptions such as voting in national elections (Day and Shaw, 2002). Other groups, however, have more to gain when acquiring citizenship, even though many countries now afford rights similar to those of citizens to their long-term residents (Castles and Davidson, 2000). At the time of the survey, being a citizen still made a difference for migrants from accession states, although this could already be envisaged to change in the near future. Therefore holding citizenship of the country of residence should be linked to less support for Europe.

\section{National Identity and Migration}

Concerns about conflicts between national and European identity are common, and it is sometimes feared that increased European integration will lead to a loss of regional or national particularities (Carey, 2002). While economic explanations have long dominated academic and public discourse about attitudes to Europe, identity theory has become a well-established and well-researched addition more recently. It would indeed seem to be the case that individuals who have a strong and exclusively defined national identity and who are rather hostile to other cultures can perceive Europe as a threat (Franklin et al., 1994; McLaren, 2002; 2007). Individuals with a European or dual identity, on the other 
hand, are more positive about the EU in general (Fligstein, 2008). Catherine De Vries and Kees Van Kersbergen (2007) bring together the economic self-interest perspective with the idea of national identity, arguing that both economic and social well-being are important for attitude formation, and that people will be less supportive if they feel that either of these are threatened.

Among migrants, national identity and pride in the nation can be expected to take a different shape than among natives. Migrants have to negotiate their sense of belonging between their ethnic group membership and the national identity of their host country (Hutnik, 1991; Modood et al., 1997; Rumbaut, 2005), and can therefore be expected to support a less exclusive notion of nationalism. Indeed, it has been found that minority groups tend to consider their ethnic identity as their primary one (Modood et al., 1997; Phalet and Swyngedouw, 2002). While this does not necessarily mean that ethnic identity excludes national selfidentification (Zimmermann et al., 2007), minorities do tend to report less national pride than the dominant group in a country (Dowley and Silver, 2000). The data used here do not allow an investigation of national identity, but using ISSP data, Frank Jones and Philip Smith (2001) find that having grown up or having lived abroad is linked to favouring a voluntaristic notion of national identity over an ascribed form, whereas citizenship is found to have the opposite effect. Similarly, individuals who travel, speak another European language and who interact with other Europeans are more likely to have a European identity (Fligstein, 2008). Furthermore, Rother and Nebe (2006) find that 'stayers' are generally more attached to the country of origin than 'movers'.

Above it was argued that citizenship is primarily important in terms of the rights it affords immigrants, but it also has a symbolic dimension (Bloemraad, 2000), so that individuals with citizenship may feel more included and identify more with the nation. Also, immigrants who feel closer to the nation state in which they reside are more likely to make the choice to apply for citizenship. Therefore it is possible that citizenship has an effect on attitudes about Europe that goes beyond the utilitarian interests discussed above, and that citizens of a particular country are less supportive than non-citizens of Europe because they identify more strongly with the nation (Jones and Smith, 2001). Citizens of the country of residence can therefore be expected to hold less favourable attitudes than noncitizens. It is also less likely that individuals who are strongly rooted in their local area will choose to migrate in the first place (Mincer, 1978), provided that they have the choice to do so, so there may be an effect of self-selection.

\section{The Impact of Self-Interest and National Identity on Migrants}

As Neil Fligstein (2008) notes, issues of identity and self-interest are difficult to disentangle both theoretically and empirically. Theories of self-interest and national identity would lead us to expect largely the same outcomes, and it is therefore not the aim here to test these theories against each other, but rather 
establish how they work together to explain how migrants feel about Europe. First, migrants should be more supportive of unification than non-migrants because of their immediate self-interest in terms of enjoying enhanced rights. The same outcome can be anticipated as a result of their less exclusive attachment to national identity. There are likely to be differences between migrants depending on their region of origin, with certain groups having gained more and having more to gain than others.

H1. Immigrants are more favourable towards further European unification than natives.

Second, this difference is expected to be larger for migrants who do not hold citizenship of their country of residence than those who do. Citizens of the residence country have little more to gain in terms of individual rights, whereas non-citizens in many cases do. Furthermore, citizenship has a symbolic dimension, and citizens may feel more attached to the nation state in which they reside than non-citizens.

H2. Holding citizenship of the country of residence has a negative effect on support for further unification.

People in lower socio-economic positions tend to support European unification less because they perceive their position to be threatened (Anderson and Reichert, 1996; Gabel, 1998; Gabel and Palmer, 1995; Huber and Stephens, 2001; Tsoukalis, 1993). For immigrants, however, this effect may be moderated by the fact that, as mobile individuals, they actually benefit from unification regardless of their skill level, so that those from lower socio-economic groups may show relatively more support than their native peers, who primarily perceive the negative aspects such as increased labour competition.

H3. Socio-economic position has a weaker effect on the attitudes of immigrants than those of natives.

Lower socio-economic groups also tend to be more parochial and have a more exclusive definition of national identity, which in turn is linked to less support for Europe (Franklin et al., 1994; McLaren, 2002; 2007). For immigrants, however, this argument is likely to hold to a lesser extent, as they have experienced mobility regardless of socio-economic background, and hence lower-skilled migrants may not be more locally oriented than the higher skilled compared to their native peers. Hence a weaker effect of occupational group, education and income is expected for immigrants than native-born respondents. 


\section{Data and Method}

The European Social Survey is used for the analysis of immigrants' attitudes to European unification here as it is the only cross-national data set that includes detailed information on immigrants' countries of origin as well as their parents' country of birth. The data are extracted from the second and third round of the ESS, and were collected between 2003 and 2006. The ESS is particularly useful for a cross-national study because it not only covers a wide range of countries, but also because it is designed to allow comparative designs by taking measures to ensure that the questions are understood in the same way across different countries and languages.

\section{Definition of Immigrants and Natives}

In the analysis, only natives and first-generation migrants were included, whereby the latter were defined as a person born abroad whose parents were also born outside his or her country of residence. If country of origin information was missing, the respondent was excluded. Natives were defined as individuals who themselves and whose parents were born in the host country and who hold citizenship.

\section{Measuring Attitudes toward European Unification}

Respondents were asked whether they thought that unification had gone too far already or whether they would like it to go further on a scale from 0 to 10 .

Higher values indicate preference for further unification. As only rounds 2 and 3 of the ESS included this variable, the amount of valid cases for migrants is 2,719 and for natives 37,757 . Missing values on the dependent variable were excluded.

\section{Human Capital and Socio-economic Position}

It is important to account for human capital characteristics of individuals surveyed, as these have been shown to have an important impact on attitudes (see for example Anderson and Reichert, 1996; Eichenberg and Dalton, 2007; Gabel, 1998). Education was measured in years of education, whereas income was measured in twelve steps that were adjusted in each country for comparability. Missing cases were replaced with the group means, with the group being defined by the combination of origin and host country, and if those were unavailable, the host country means. Occupation was coded as legislators, senior officials, managers and professionals as the highest category; technicians, associated professionals and clerks as the next lower category; service workers, skilled agricultural and fishery and crafts as a third category; and all others as the fourth category. 


\section{Origin and Destination Countries}

Only data from individuals who are resident in the EU-15 countries were used. Migrants were divided into four categories: those who migrated within the EU15; those from the ten countries that joined in 2004; those from candidate countries Bulgaria and Romania, which have since then joined the EU, plus Turkey, Croatia, Macedonia and possible candidates Albania, Kosovo, Serbia, Bosnia and Herzegovina and Montenegro (European Commission, 2009). All other migrants belong to the fourth category of third country migrants.

Citizenship status was assessed by respondents' indication of whether they hold citizenship or not. At the time of the survey, being a citizen still made a difference for migrants from accession member states, although this could already be envisaged to change in the near future.

\section{Modelling}

MLwiN 2.02 was used to specify a hierarchical linear model with two levels. Individuals are specified as level one $(n=40,476)$ and country of residence as level two $(n=15)$. Random intercepts were specified for the higher level. All models have been estimated using full maximum likelihood estimation implemented as IGLS in MLN. Age, gender and main source of income are used as control variables from Model II onwards. Table 1 summarises the independent variables for natives and immigrants broken down by different origin regions.

Table 1. Variable Description

\begin{tabular}{|c|c|c|c|c|c|}
\hline & \multirow[b]{2}{*}{ Native } & \multicolumn{4}{|c|}{ Immigrant } \\
\hline & & $E U-15$ & New EU & Candidate & Non-EU \\
\hline Age & 47.8 & 47.9 & 46.7 & 39.4 & 40.3 \\
\hline \multicolumn{6}{|l|}{ Gender } \\
\hline$\%$ male & 48.0 & 48.8 & 36.2 & 51.6 & 49.4 \\
\hline \multicolumn{6}{|l|}{ Income source } \\
\hline$\%$ employment & 67.0 & 71.7 & 63.2 & 74.9 & 75.3 \\
\hline$\%$ pension & 26.0 & 21.4 & 25.1 & 12.0 & 9.6 \\
\hline$\%$ welfare & 5.2 & 4.9 & 8.2 & 10.7 & 11.2 \\
\hline$\%$ other & 1.8 & 1.9 & 3.5 & 2.4 & 3.8 \\
\hline Income & 6.6 & 7.3 & 6.4 & 6.0 & 6.3 \\
\hline Education & 12.0 & 12.0 & 13.3 & 11.2 & 12.7 \\
\hline \multicolumn{6}{|l|}{ Occupation } \\
\hline$\%$ professional & 23.0 & 26.8 & 27.7 & 10.8 & 20.2 \\
\hline$\%$ clerks/service & 28.0 & 22.8 & 27.7 & 13.7 & 19.9 \\
\hline$\%$ crafts/trades & 31.1 & 28.2 & 28.3 & 40.6 & 32.8 \\
\hline$\%$ others & 17.9 & 22.1 & 16.2 & 34.9 & 27.1 \\
\hline \multicolumn{6}{|l|}{ Citizenship } \\
\hline$\%$ citizen & $\mathrm{n} / \mathrm{a}$ & 28.3 & 64.9 & 42.8 & 55.7 \\
\hline $\mathrm{N}$ & 37757 & 911 & 188 & 445 & 1175 \\
\hline
\end{tabular}




\section{Analysis and Findings}

As expected in Hypothesis 1, findings in Model I (Table 2) show that immigrants are more in favour of further unification than natives. The difference to natives is most pronounced for immigrants from candidate countries, but also highly significant for all other immigrant groups. For comparison, it is larger for all groups than, for example, the difference between an unskilled worker and a professional among the native population, and even substantially larger for some groups. Between-group differences are not significant for EU-15, EU-10 and third country migrants, but candidate migrants are significantly more favourable than all other immigrant groups. These coefficients change very little when control variables are introduced in Model II. Demographic variables show few surprises, with individuals depending on state transfers being less favourable towards Europe, and the same holds for women and older people. Higher socio-economic status measured as income, education and occupational group is linked to more positive attitudes. 


\begin{tabular}{|c|c|c|c|c|c|c|c|c|}
\hline & \multicolumn{2}{|l|}{ Modell } & \multicolumn{2}{|l|}{ Model II } & \multicolumn{2}{|l|}{ Model IIII } & \multicolumn{2}{|l|}{ Model IV } \\
\hline & Coeff. & $S E$ & Coeff. & $S E$ & Coeff. & $S E$ & Coeff. & $S E$ \\
\hline Intercept & $4.976^{* * * *}$ & 0.180 & $4.814^{* * * *}$ & 0.194 & $4.813^{* * * *}$ & 0.195 & $4.798^{* * *}$ & 0.196 \\
\hline Age & & & $-0.010^{* * * *}$ & 0.001 & $-0.010^{* * *}$ & 0.001 & $-0.010^{\star \star \star *}$ & 0.001 \\
\hline \multicolumn{9}{|l|}{ Gender (ref. male) } \\
\hline Female & & & $-0.211^{\text {****}}$ & 0.026 & $-0.210^{* \star * *}$ & 0.026 & $-0.209^{* * *}$ & 0.026 \\
\hline \multicolumn{9}{|l|}{ Income source (ref. emp.) } \\
\hline Pension & & & 0.078 & 0.041 & 0.079 & 0.041 & $0.083_{-}^{*}$ & 0.041 \\
\hline Welfare/unemp. & & & -0.047 & 0.061 & -0.046 & 0.061 & -0.047 & 0.061 \\
\hline Other & & & $0.277_{-}^{\star \star}$ & 0.098 & $0.271_{-}^{* \star}$ & 0.098 & $0.272_{-}^{\star \star}$ & 0.098 \\
\hline Income & & & $0.036^{\star \star * \star *}$ & 0.008 & $0.036^{\text {****}}$ & 0.008 & $0.037^{\star \star \star \star}$ & 0.008 \\
\hline Education & & & $0.040^{* \star * *}$ & 0.004 & $0.040^{* * * *}$ & 0.004 & $0.044^{\star \star * \star}$ & 0.004 \\
\hline \multicolumn{9}{|l|}{ Occupation (ref. others) } \\
\hline Professional & & & $0.618^{* \star \star *}$ & 0.047 & $0.616^{\text {*** }}$ & 0.047 & 0.639 *** & 0.049 \\
\hline Clerks & & & $0.320^{* \star \star *}$ & 0.042 & $0.319^{* * *}$ & 0.042 & $0.341^{* * * *}$ & 0.044 \\
\hline Service/trades & & & $0.098_{-}^{*}$ & 0.039 & $0.096_{-}^{*}$ & 0.039 & $0.098_{-}^{*}$ & 0.041 \\
\hline \multicolumn{9}{|c|}{ Immigrant status (ref. native) } \\
\hline EU-15 & $0.600^{* * * *}$ & 0.091 & $0.636^{* * * *}$ & 0.089 & $0.705^{* * * *}$ & 0.106 & $0.887^{\star * * *}$ & 0.150 \\
\hline EU-10 & $0.850^{* * * *}$ & 0.188 & $0.825^{\text {****}}$ & 0.185 & 1.240 **** & 0.311 & $1.440^{* * * *}$ & 0.329 \\
\hline Candidate & $1.358_{=}^{* * * *}$ & 0.123 & $1.421^{\text {**** }}$ & 0.122 & $1.785^{* * *}$ & 0.160 & $1.809^{* * * *}$ & 0.187 \\
\hline Third country & $0.741^{* * * *}$ & 0.076 & $0.689^{* \star * *}$ & 0.076 & $0.953^{* * *}$ & 0.112 & $1.085^{* \star *}$ & 0.150 \\
\hline \multicolumn{9}{|c|}{ Immigrant status $\times$ citizenship (ref. non-citizens of relevant status) } \\
\hline EU-15 & & & & & -0.216 & 0.188 & -0.246 & 0.188 \\
\hline EU-10 & & & & & -0.642 & 0.386 & -0.613 & 0.387 \\
\hline Candidate & & & & & $-0.843^{* \star * *}$ & 0.243 & $-0.778_{-}^{* \star}$ & 0.244 \\
\hline Third country & & & & & $-0.470_{-}^{* \star}$ & 0.149 & $-0.443_{-}^{\star \star}$ & 0.149 \\
\hline Immigrant $\times$ income & & & & & & & -0.008 & 0.027 \\
\hline Immigrant $\times$ education & & & & & & & $-0.036_{-}^{* \star}$ & 0.013 \\
\hline \multicolumn{9}{|l|}{ Immigrant $\times$ occupation } \\
\hline Professional & & & & & & & $-0.377_{-}^{\star}$ & 0.178 \\
\hline Clerks & & & & & & & $-0.351_{-}^{*}$ & 0.167 \\
\hline Service/trades & & & & & & & 0.058 & 0.143 \\
\hline Variance components & Variance & $S E$ & Variance & $S E$ & Variance & $S E$ & Variance & $S E$ \\
\hline Country & $0.483_{-}^{* *}$ & 0.178 & $0.546_{-}^{* *}$ & 0.200 & $0.547_{-}^{* \star}$ & 0.201 & $0.553_{-}^{* *}$ & 0.203 \\
\hline Individual & $6.555^{\text {****}}$ & 0.046 & $6.370^{* * *}$ & 0.045 & $6.366^{* * *}$ & 0.045 & $6.361^{\text {****}}$ & 0.045 \\
\hline Number of cases & \multicolumn{8}{|c|}{$n_{1}=40,476, n_{2}=15$} \\
\hline \multicolumn{9}{|c|}{$\begin{array}{l}\text { Notes: Dependent variable: 'Europea } \\
<0.001 . \\
\text { Source: European Social Survey. }\end{array}$} \\
\hline
\end{tabular}

In Model III citizenship is included to assess its impact. As predicted in Hypothesis 2, migrants who hold citizenship of their country of residence are less in favour of further unification than non-citizens. However, migrants who are citizens are still more favourable than natives overall. The citizenship effect is roughly comparable in size to the difference between a professional and a lowskilled worker among natives for all immigrant groups, with the exception of EU15 migrants, where the effect is smaller, and not significant. For new EU member state migrants, the negative citizenship effect remains below conventional significance levels, which is most likely due to the small number $(n=66)$ of non- 
citizens in this category. The citizenship effect is strongest and highly significant for candidate state migrants, but also quite pronounced for third country migrants. Figure 1 illustrates these differences based on results in Model III.

Figure 1. Native vs. Immigrant Attitudes

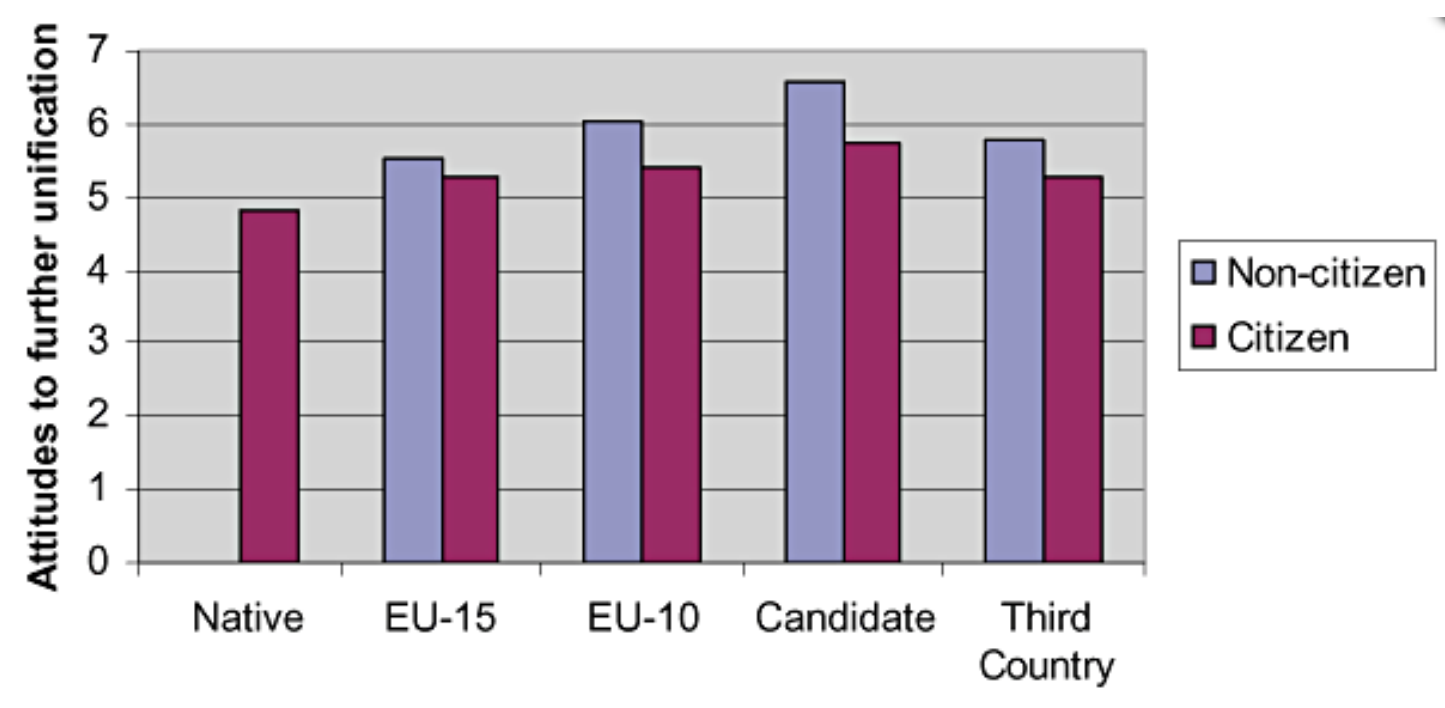

Figure 1. Native vs. Immigrant Attitudes

Model IV estimates the differential impact of human capital and occupational groups on immigrants' attitudes. Hypothesis 3 is supported, with socio-economic status playing a weaker role for the attitudes of immigrants compared to natives, as the negative interaction effects for income (non-significant), education and occupational status show. Figure 2 illustrates these differences along occupational group for natives versus EU-15 migrants based on Model IV. Professionals and clerks tend to be more favourable towards European unification than service workers and tradesmen, and this also holds for immigrants, but these differences are significantly smaller for migrants than for natives. A professional migrant is still comparatively more supportive than a professional native, but the difference between them is smaller than that, for example, between a native compared to an immigrant tradesman or unskilled worker. 


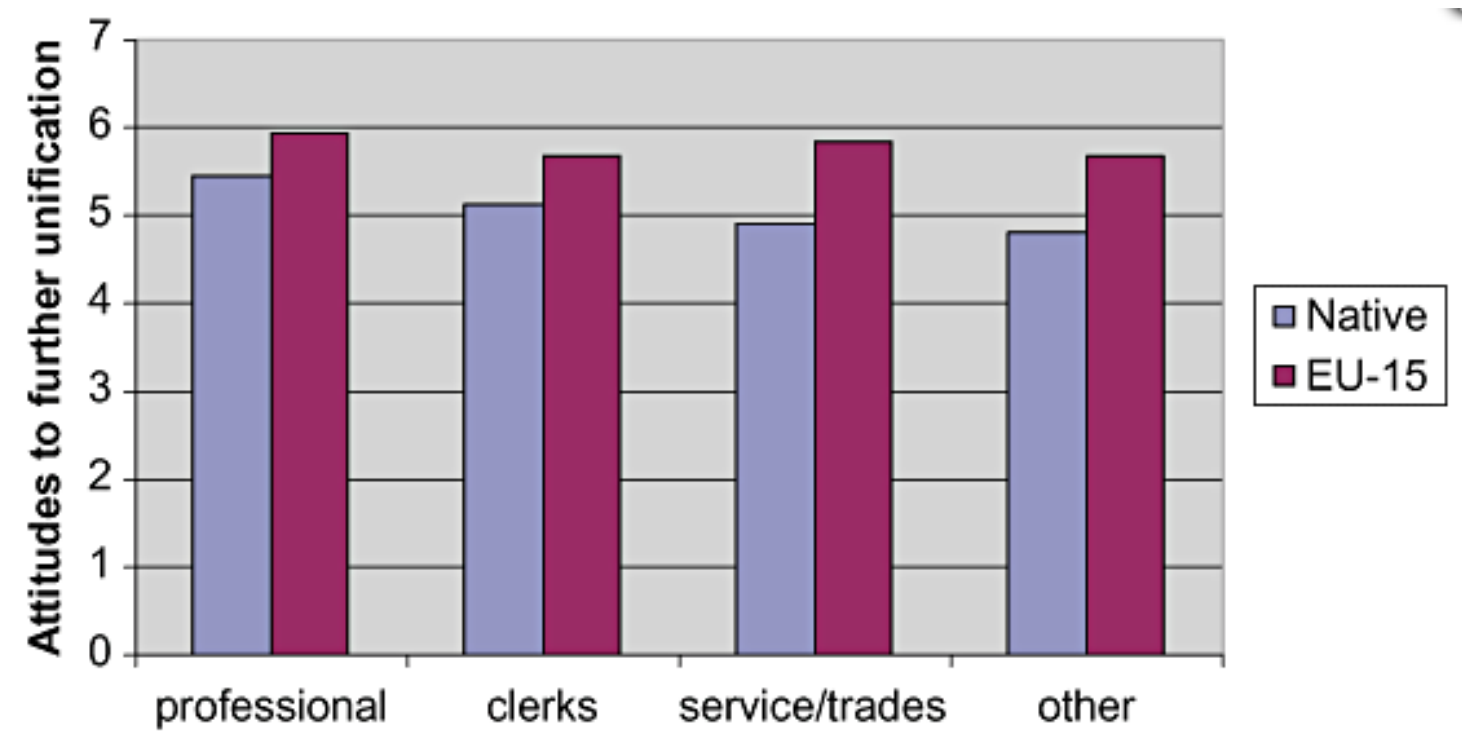

Figure 2. Occupation Interaction

Generally, higher education leads to more support for Europe, but for migrants this link is significantly weaker, which is illustrated by the different slopes for the education effect for immigrants and natives depicted in Figure 3. For immigrants, education hardly matters, whereas it has quite an important effect on natives' attitudes. Equally, higher income is associated with more positive attitudes, but again this effect is weaker for immigrants (non-significant). As there is a large overlap between income, education and occupational group, these interaction effects are stronger, and the income effect significant, if separate models are estimated that are not reported here. 
Figure 3. Education Interaction

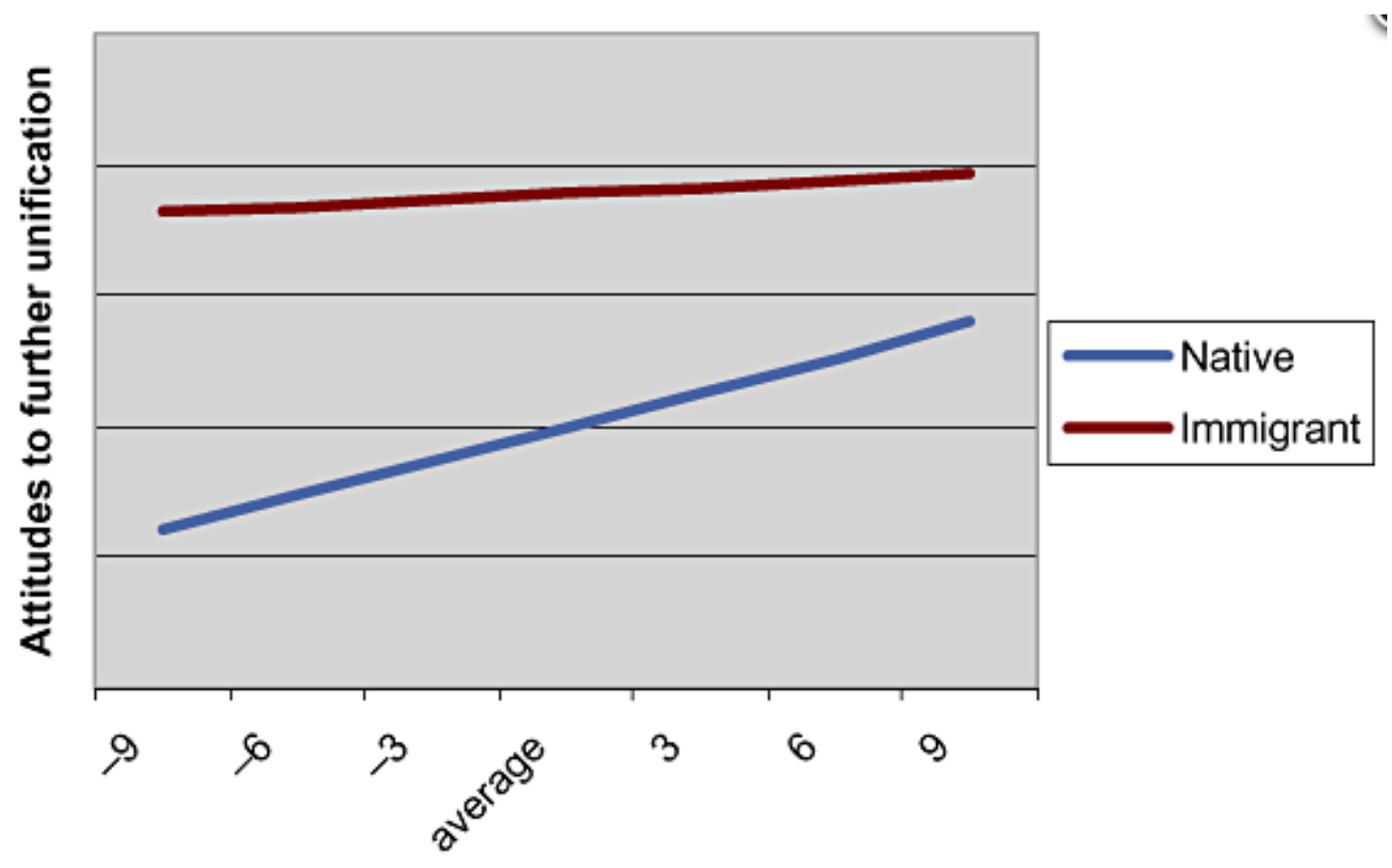

Figure 3. Education Interaction

\section{Discussion and Conclusion}

While the issue of European integration has become more contentious (Hooghe and Marks, 2006; Kriesi, 2007), there are still some groups that are measurably more supportive. Findings here show that individuals who live in a different country from the one in which they were born form one of these groups. This seems to be the case across different origin regions, although some differences were observed, with immigrants from candidate countries being the most supportive. As Hanspeter Kriesi (2007) argues, there is a 'new cultural cleavage' between the losers and winners of globalisation that is linked to Euroscepticism, which seems supported by the findings here, if immigrants are considered as 'winners' of globalisation and European integration. In fact, differences based on migration and citizenship status are quite large when compared to those between 'losers' and 'winners' defined, for example, in terms of occupational groups. Two key reasons for opposition to European unification, economic competition and cultural threat are absent or weaker in the case of immigrants, who benefit economically from free movement and are less likely to find a multicultural Europe threatening. 
Findings suggest that a cost-benefit analysis is taking place that is related to what has already been achieved by the EU in the past and what may still be achieved: all migrants want more unification as compared to natives, even if further unification will not enhance the situation of all groups equally. The major gains from European unification have already been made for migrants from within EU territory. They may favour unification because it would further simplify their interactions with institutions in the future, whereas migrants from third countries may hope for an improvement of their status as a result of the integration of European migration policy. The most interesting outcome perhaps is the remarkably positive attitudes of migrants from countries that are at the borders of Europe. It would appear that candidate state immigrants had enlargement of the EU on their minds when they replied to the question that was intended to measure attitudes to unification, as further integration of the current members would not enhance the status of this group, whereas enlargement would benefit individuals from these countries greatly in terms of ease of movement within the Union, contact with their origin countries and enhanced legal and political rights in the residence countries. This suggests that future benefits seem to be a particularly strong motivator for support for Europe.

National attachment and identity also provide a possible explanation for the more positive attitudes of migrants, however. The cost-benefit framework may be better suited to explain the differences between migrants from different origin regions, but the overall more positive attitudes could equally be, at least partly, the outcome of a less exclusive national attachment of this group and a readiness to identify with the supranational level as a direct outcome of their own migration experience. The results regarding citizenship can similarly be attributed to both frameworks: first, migrants who hold citizenship of their host countries have less to gain on the individual level from unification or enlargement; and second, they may also feel more attached to their host country and hence prefer the national over the European level.

Findings not only show that being a migrant and citizenship status are important in determining attitudes, but also that the effect of generally strong predictors such as occupational status, income and education is weaker for migrants than it is for the native population. As it cannot be determined here whether the positive effect of being a migrant is mostly due to a weaker national identification or particular interests both in terms of past and future benefits of European unification, this finding can mean two things: first, the argument about the lower skilled being threatened by European unification is less valid for immigrants, who have profited from mobility regardless of occupational status; and second, that while higher socio-economic status is generally linked to less exclusive national attitudes for natives (Jones and Smith, 2001), this difference may not be relevant for migrants. The lower skilled may be proportionally less parochial than their native peers as a result of their experience of mobility, explaining the smaller differences along occupational and socio-economic status among immigrants. 
This study is limited in so far as it could only assess attitudes towards unification, and not other aspects such as the enlargement of the EU or support for its policies, which would provide a clearer picture of the interests different migrant groups have. The main issue, however, is that national identity could not be considered in the model as a mediating factor for the more favourable attitudes of migrants in comparison to natives so it is not possible to disentangle the impact it may have on attitudes from the role particular interests play. Further research may be able to pick up on these limitations to explore in more detail how the migrant population of Europe feels about particular European issues. Another related area that might merit exploration is how far mobility influences natives' attitudes, as people who have lived abroad for significant periods of their lives, such as return migrants or individuals taking advantage of work and study exchange programmes, might display similar patterns to immigrants as a result of this experience.

\section{About the Author}

Antje Roeder is a doctoral student in the Department of Sociology and the Institute for International Integration Studies of Trinity College Dublin. Her PhD research, which is part of the Trinity Immigration Initiative, investigates the attitudes and values of immigrants in Europe as well as their socio-cultural integration. Other research interests are attitudes to immigration, European unification and trust in institutions.

Antje Roeder, Institute for International Integration Studies, Trinity College Dublin, Dublin 2, Ireland; email: roedera@tcd.ie

\section{Note}

I would like to thank Peter Mühlau, Torben Krings and Alex Herzog and the three anonymous reviewers for their helpful comments and suggestions on earlier drafts of this research note. Financial support from the Trinity Immigration Initiative is gratefully acknowledged.

\section{References}

Anderson, C. J. and Reichert, S. (1996) 'Economic Benefits and Support for Membership in the EU: A Cross-National Analysis', Journal of Public Policy, 15 (3), 231-49. 
Bloemraad, I. (2000) 'Citizenship and Immigration: A Current Review', Journal of International Migration and Integration, 1 (1), 9-37.

Carey, S. (2002) 'Undivided Loyalties: Is National Identity an Obstacle to European Integration?', European Union Politics, 6 (1), 29-57.

Castles, S. and Davidson, A. (2000) Citizenship and Migration: Globalization and the Politics of Belonging. New York: Routledge.

Day, S. and Shaw, J. (2002) 'European Union Electoral Rights and the Political Participation of Migrants in Host Polities', International Journal of Population Geography, 8 (2), 183-99.

De Vries, C. E. and Van Kersbergen, K. (2007) 'Interests, Identity and Political Allegiance in the European Union', Acta Politica, 42 (2/3), 307-28.

Dowley, K. M. and Silver, B. D. (2000) 'Subnational and National Loyalty: CrossNational Comparisons', International Journal of Public Opinion Research, 12 (4), 357-71.

Easton, D. (1975) 'A Re-assessment of the Concept of Political Support', British Journal of Political Science, 5 (4), 435-57.

Eichenberg, R. C. and Dalton, R. J. (2007) 'Post-Maastricht Blues: The Transformation of Citizen Support for European Integration, 1973-2004', Acta Politica, 42 (2/3), 128-52.

European Commission (2007) 'Third Annual Report on Migration and Integration', European Commission [online]. Available from: http://ec.europa.eu/justice_home/fsj/immigration/docs/com_2007512_en.pdf[Accessed 23 September 2009].

European Commission (2009) 'Enlargement', European Commission [online]. Available from:

http://ec.europa.eu/enlargement/countries/index_en.htm[Accessed 23 September 2009].

Favell, A. (2008) 'The New Face of East-West Migration in Europe', Journal of Ethnic and Migration Studies, 34 (5), 701-16.

Fligstein, N. (2008) Euro-Clash: The EU, European Identity, and the Future of Europe. Oxford: Oxford University Press.

Franklin, M., Marsh, M. and McLaren, L. (1994) 'The European Question: Opposition to Unification in the Wake of Maastricht', Journal of Common Market Studies, 32 (4), 455-72.

Gabel, M. J. (1998) 'Public Support for European Integration: An Empirical Test of Five Theories', The Journal of Politics, 60 (2), 333-54. 
Gabel, M. J. and Palmer, H. D. (1995) 'Understanding Variation in Public Support for European Integration', European Journal of Political Research, 27 (1), 3-19.

Hooghe, L. and Marks, G. (2005) 'Calculation, Community and Cues', European Union Politics, 6 (4), 419-43.

Hooghe, L. and Marks, G. (2006) 'Europe's Blues: Theoretical Soul-Searching after the Rejection of a European Constitution', PS: Politics and Political Science, 39 (2), 247-50.

Huber, E. and Stephens, J. (2001) Political Choice in Global Markets:

Development and Crisis of Advanced Welfare States. Chicago IL: Chicago University Press.

Hutnik, N. (1991) Ethnic Minority Identity: A Social-Psychological Perspective. Oxford: Clarendon Press.

Jones, F. L. and Smith, P. (2001) 'Individual and Societal Bases of National Identity: A Comparative Multi-level Analysis', European Sociological Review, 17 (2), 102-18.

Kriesi, H. (2007) 'The Role of European Integration in National Election Campaigns', European Union Politics, 8 (1), 83-108.

McLaren, L. M. (2002) 'Public Support for the European Union: Cost/Benefit Analysis or Perceived Cultural Threat?', The Journal of Politics, 64 (2), 551-66.

McLaren, L. M. (2007) 'Explaining Mass-Level Euroscepticism: Identity, Interests, and Institutional Distrust', Acta Politica, 42 (2/3), 233-51.

Mincer, J. (1978) 'Family Migration Decisions', The Journal of Political Economy, 86 (5), 749-73.

Modood, T., Berthoud, R., Lakey, J., Nazroo, J., Smith, P., Virdee, S. and Beishon, S. (1997) Ethnic Minorities in Britain: Diversity and Change. London: PSI.

Münz, R., Straubhaar, T., Vadean, F. and Vadean, N. (2007) 'What Are the Migrants' Contributions to Employment and Growth? A European Approach', IAW-Report, 35 (1), 1-34.

Phalet, K. and Swyngedouw, M. (2002) 'National Identities and Representations of Citizenship: A Comparison of Turks, Moroccans and Working-Class Belgians in Brussels', Ethnicities, 2 (1), 5-30.

Quinlan, S. (2009) 'The Lisbon Treaty Referendum', Irish Political Studies, 24 (1), 107-21.

Recchi, E. (2008) 'Cross-State Mobility in the EU: Trends, Puzzles and Consequences', European Societies, 10 (2), 197-224.

Rother, N. and Nebe, T. (2006) 'The Question of European Identity'. Paper presented at the Final Conference of the PIONEUR project 'Mobility and the 
Emergence of European Identity among National and Foreign Citizens in the EU', Florence, 10 March.

Rumbaut, R. G. (2005) 'Sites of Belonging: Acculturation, Discrimination and Ethnic Identity among Children of Immigrants', in T. S.Weisner (ed.), Discovering Successful Pathways in Children's Development. Chicago IL: University of Chicago Press, pp. 111-64.

Stalker, P. (2003) 'Migration Trends and Migration Policy in Europe', International Migration, 40 (5), 151-79.

Tsoukalis, L. (1993) The New European Economy, 2nd edition. Oxford: Oxford University Press.

Check TCD e-journals

Tucker, J. A., Pacek, A. C. and Berinsky, A. J. (2002) 'Transitional Winners and Losers: Attitudes toward EU Membership in Post-communist Countries', American Journal of Political Science, 46 (3), 557-71.

Vetik, R. (2003) 'Elite vs. People? Eurosceptic Public Opinion in Estonia', Cambridge Review of International Affairs, 16 (2), 257-71.

Weßels, B. (2007) 'Discontent and European Identity: Three Types of Euroscepticism', Acta Politica, 42 (2/3), 287-306.

Zimmermann, L., Zimmermann, K. F. and Constant, A. (2007) 'Ethnic SelfIdentification of First-Generation Immigrants', International Migration Review, 41 (3), 769-81. 